\title{
Proatlantal intersegmental artery with internal carotid artery stenosis
}

Figure CT and catheter-based angiograms
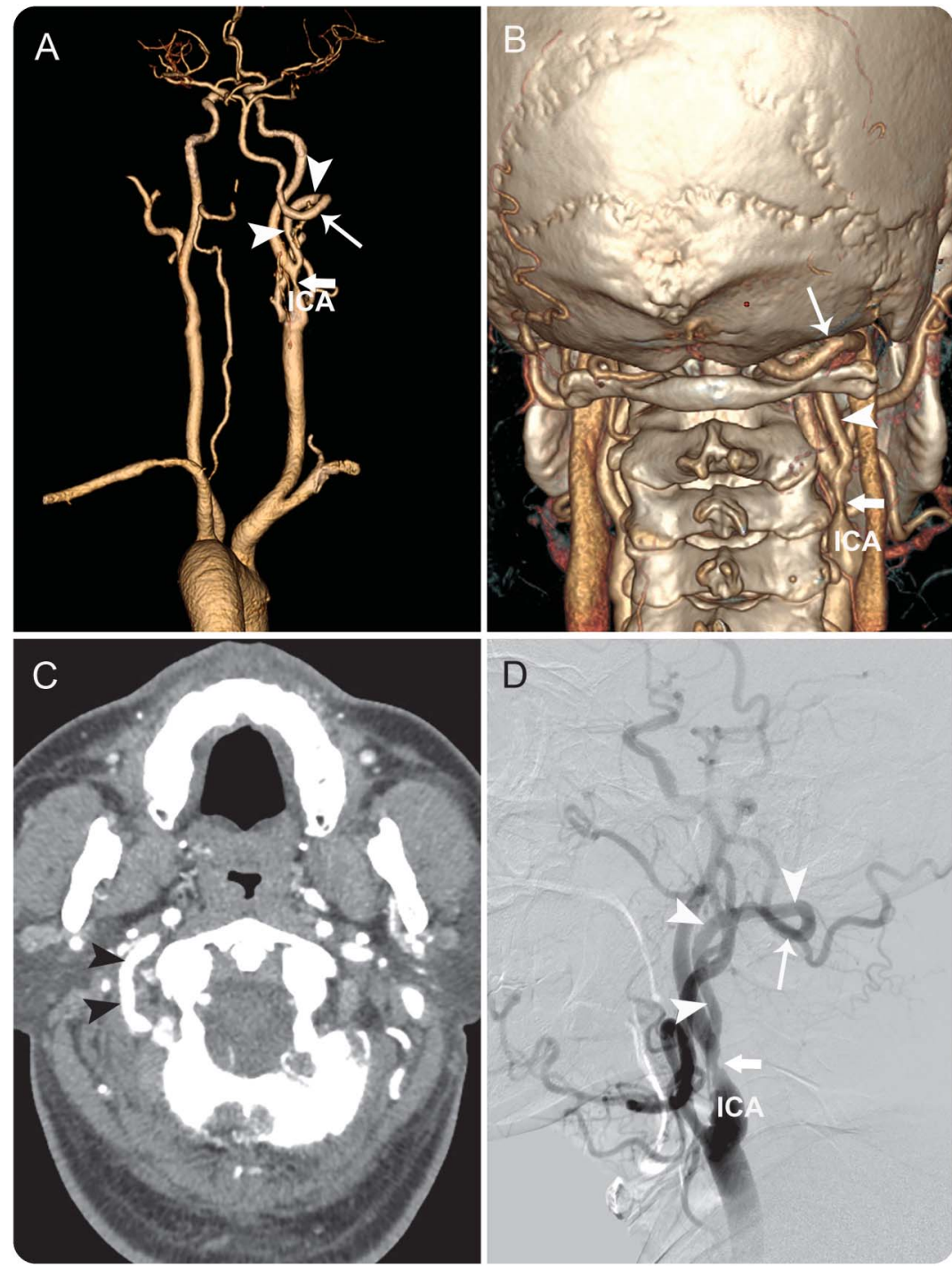

(A-C) CT angiograms (posterior view) show an internal carotid artery (ICA) stenosis (thick arrow) and a type 1 proatlantal intersegmental artery (arrowheads) originating from the ICA, running upward, and joining the ipsilateral vertebral artery (thin arrow). (D) Catheter-based angiogram shows an approximately $60 \%$ stenosis (thick arrow) of the right ICA.

A 56-year-old man presented with vertigo of 4 days duration. Neurologic examination was unremarkable. CT angiograms revealed a right internal carotid artery (ICA) stenosis and an ipsilateral proatlantal intersegmental artery (PIA, type 1). The PIA arose from the ICA, ran upward, then took a dorsal course, and continued as the vertebral artery, serving as the major contributor of the posterior circulation (figure, A-C). Catheter-based angiogram showed ICA stenosis of $60 \%$ (figure, D). He chose drug therapy and remained asymptomatic on follow-up. Such combination can lead to TIA of the vertebrobasilar system; treatment options include endarterectomy, stenting, balloon angioplasty, or medication. ${ }^{1,2}$ 
Weidong Yu, MS, * Zheng Feng, MS, * Conghai Zhao, MD, Chao Fu, MS

*These authors contributed equally to this work.

From the Department of Neurosurgery (W.Y., C.Z., C.F.) and Pediatrics (Z.F.), China-Japan Union Hospital of Jilin University, Changchun, Jilin Province, People's Republic of China.

Author contributions: Dr. Yu: acquisition of data, study concept or design, drafting/revising the manuscript, accepts responsibility for conduct of research and final approval. Dr. Feng: acquisition of data, study concept or design, drafting/revising the manuscript, accepts responsibility for conduct of research and final approval. Dr. Zhao: acquisition of data, study concept or design, drafting/revising the manuscript, accepts responsibility for conduct of research and final approval. Dr. Fu: acquisition of data, study concept or design, drafting/revising the manuscript, accepts responsibility for conduct of research and final approval.

Study funding: No targeted funding reported.

Disclosure: The authors report no disclosures relevant to the manuscript. Go to Neurology.org for full disclosures.

Correspondence to Dr. Fu: fc616@126.com

1. Grego F, Stramanà R, Lepidi S, et al. Primitive proatlantal intersegmental artery and carotid endarterectomy. J Vasc Surg 2004; 39:691.

2. Morales M, Anacleto A, Berbert M, et al. Endovascular treatment for recurrent carotid stenosis in a patient with proatlantal intersegmental artery. J Vasc Interv Radiol 2006;17:399-400.

\section{WriteClick ${ }^{\circledR}$ rapid online correspondence}

Have a comment on a recent Neurology ${ }^{\circledR}$ article you would like to share? Now it is easier and more convenient. Neurology.org has launched WriteClick on the home page and sidebars of each article to encourage remarks and debate among users.

WriteClick is restricted to comments about studies published in Neurology within the last eight weeks.

Learn more at Neurology.org/letters

\section{Discover Altmetrics}

See real-time downloads and online activity for articles!

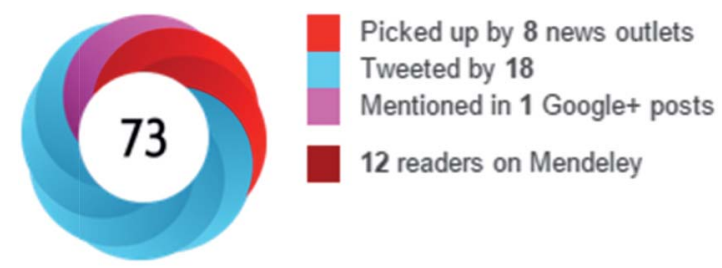

See more details

Authors and readers alike can view real-time data on articles including downloads and online activity across multiple sources. Click on the "Article Metrics" link in the right column of an article for details. To learn more about article metrics visit http://www.neurology.org/site/misc/article_usage.xhtml. 


\section{Neurology}

\section{Proatlantal intersegmental artery with internal carotid artery stenosis \\ Weidong $\mathrm{Yu}$, Zheng Feng, Conghai Zhao, et al. \\ Neurology 2017;89;104-105 \\ DOI 10.1212/WNL.0000000000004068}

\section{This information is current as of July 3, 2017}

\section{Updated Information \& Services}

References

Subspecialty Collections

Permissions \& Licensing

Reprints including high resolution figures, can be found at: http://n.neurology.org/content/89/1/104.full

This article cites 2 articles, 0 of which you can access for free at: http://n.neurology.org/content/89/1/104.full\#ref-list-1

This article, along with others on similar topics, appears in the following collection(s):

All Cerebrovascular disease/Stroke

http://n.neurology.org/cgi/collection/all_cerebrovascular_disease_strok

All Clinical Neurology

http://n.neurology.org/cgi/collection/all_clinical_neurology

CT

http://n.neurology.org/cgi/collection/ct

Information about reproducing this article in parts (figures,tables) or in its entirety can be found online at:

http://www.neurology.org/about/about_the_journal\#permissions

Information about ordering reprints can be found online:

http://n.neurology.org/subscribers/advertise

Neurology ${ }^{\circledR}$ is the official journal of the American Academy of Neurology. Published continuously since 1951, it is now a weekly with 48 issues per year. Copyright @ 2017 American Academy of Neurology. All rights reserved. Print ISSN: 0028-3878. Online ISSN: 1526-632X.

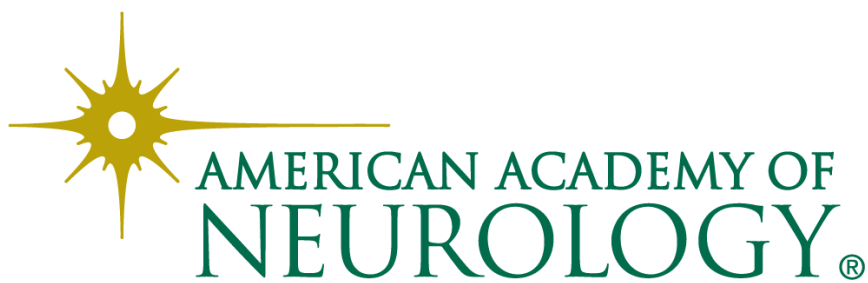

